Ann. Biol. anim. Bioch. Biophys., 1978, 18 (4), 899-904.

\title{
Cyclic changes in the testis and vas deferens of the rainbow trout (Salmo gairdneri) with special reference to sites of steroidoge- nesis
}

par R. VAN DEN HURK, J. A. J. VERMEIJ, J. STEGENGA, J. PEUTE, P. G. W. J. VAN OORDT

Zoological Laboratory, Section Comparative Endocrinology, University of Utrecht, Transitorium III, Padualaan 8, Utrecht, The Netherlands.

Summary. Enzyme cytochemical and electron microscopical data indicate Leydig cells as the main source of steroids in the testis of Salmo gairdneri. Steroidogenesis in Leydig cells is found during the annual testis cycle, with a peak in activity from January to June, $i$. e. the period when the testes are mature and new primary spermatogonia are formed. In June, Leydig cells are mainly found around seminiferous tubules containing secondary spermatogonia. Enzymes involved in steroidogenesis are also present in Sertoli cells of November animals during spermiation. Steroid formation has furthermore been demonstrated in stroma cells distributed in the connective tissue around the epithelium of the vas deferens. Steroidogenic activity in these stroma cells is stronger in the period when sperm cells are stored in the lumen of the vas deferens.

\section{Introduction.}

Several papers have dealt with the morphology of the testis of the rainbow trout Salmo gairdneri. The anatomy of the urogenital system of the trout was described by Henderson (1967), and the histology of the testis by Weisel (1943), Oota ef al. (1965) and Boddingius (1975).

Several authors have discussed possible sites of gonadal hormone production. Robertson (1958) considered the Leydig cells as endocrine structures, but this was not confirmed by Boddingius (1975). Oota and Yamamoto (1966) presented ultrastructural evidence of steroidogenesis in Leydig cells. In some teleosts a steroidogenic function is ascribed to lobule boundary cells or Sertoli cells (Lofts and Bern, 1972) ; but this role was not substantiated in rainbow trout by ultrastructural data (Billard ef al., 1972).

The present study deals with the localization of steroid formation and the estimation of steroid synthesizing capacity in the testis and vas deferens of Salmo gairdneri using enzyme cytochemical methods. Electron microscopy was carried out to detect possible sites of steroidogenesis in the testis. A brief histological description of the annual spermatogenetic cycle is presented as a basis for these studies. 


\section{Material and methods.}

Thirty male specimens of three-year old rainbow trout, Salmo gairdneri Richardson, were obtained from a trout hatchery in Vaassen (the Netherlands), in 1975 on June 3, August 7. September 24, and November 4, and in 1976 on January 7, February 25 and May 5. The animals were anesthetized with 0.035 p. 100 MS 222 or carbogen gas, followed by decapitation and removal of the testes and vasa deferentia. Histological studies were carried out on $4 \mu \mathrm{m}$ sections of tissue fixed in Smith's formaldehyde-bichromate. Cytochemical tests were performed with $10 \mu \mathrm{m}$ sections of tissues frozen at $-20{ }^{\circ} \mathrm{C}$ with $\mathrm{CO}_{2}$. For histology and cytochemistry, sections were cut from various parts of the testis and rostral part of the vas deferens. The following enzyme reactions were carried out : $3 \beta$ and $3 \alpha$-hydroxy steroid dehydrogenase ( $3 \beta$ - and $3 \alpha-$ HSD) using the method of Baillie et al. modified by van den Hurk (1973), and glucose6-phosphate dehydrogenase (G6PD) using the method of Rudolph and Klein as modified by van den Hurk (1973). Intensity of the enzyme reactions was graded in arbitrary units, as follows : no reaction, $(-)$; moderate, $(++)$; and strong. $(+++)$.

For electron microscopy, medial and distal parts of the testis were fixed according to Peute ef al. (1976). The tissues were then dehydrated in graded ethanol and propyleneoxide, and subsequently embedded in Epon. Thin sections were examined with a Philips EM 300.

\section{Results.}

The festis of the rainbow trout is tubular (van den Hurk, 1973) with a network of efferent ducts situated on the mesorchial side. The seminiferous tubules are connected with a vas deferens by the efferent duct system. On the basis of histology, three periods can be distinguished in the spermatogenetic cycle :

1. The multiplication period from June to September is characterized by the formation of increasing numbers of cysts containing secondary spermatogonia. In June these cysts are present mainly at the mesorchial side of the testis, but in August they can be observed in all seminiferous tubules.

2. During the maturation period from September to January, primary spermatocytes are formed, and maturation divisions and spermiogenesis are in progress. From November, the testis tubules and vasa deferentia are filled with masses of ripe sperm.

3. The period of functional maturity commences when spermatogenesis is complete in January and lasts until June. In the Dutch hatcheries, rainbow trout do not spawn spontaneously. Between February and June, the sperm cells in the testis tubules and the efferent duct system are resorbed by Sertoli cells. To that end Sertoli cells form protrusions into the lumen of the tubule and subsequently become detached from the tubule wall. Desintegrating sperm cells remain visible in the efferent ducts until September. The third period may also be referred to as the period of accumulation of primary spermatogonia. These primary spermatogonia are situated in the peri- 
phery of the testis fubules and are surrounded by Sertoli cells. In January, primordial germ cells invade the interstitium and change into primary spermatogonia when surrounded by Sertoli cells in the wall of the testis tubules. The greatest increase in the number of primordial germ cells and primary spermatogonia is in February. The number of primary spermatogonia continues to increase until June, whereas the number of primordial germ cells decreases after February.

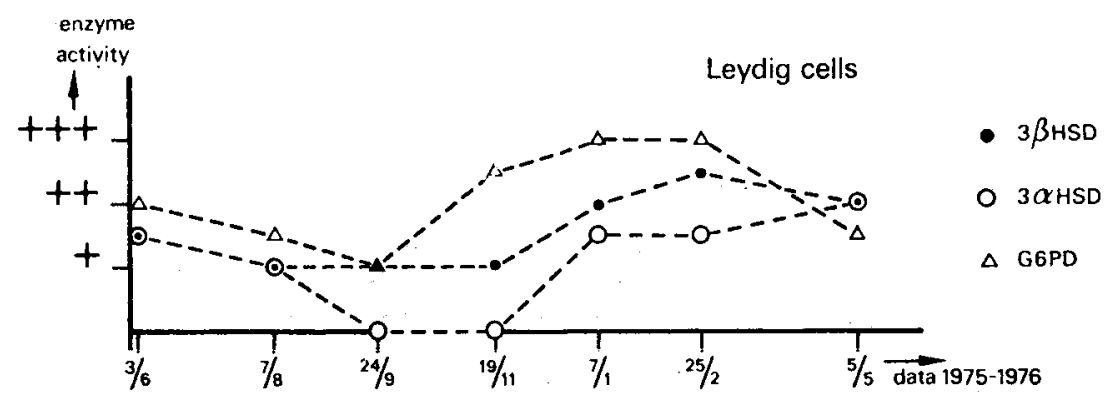

FIG. 1. - 3 $3-\mathrm{HSD}, 3 \alpha-\mathrm{HSD}$ and G6PD activity in Leydig cells during the annual cycle.

The activity of steroidogenic enzymes - 3 $\beta-H S D, 3 \alpha-H S D$ and G6PD - is almost entirely confined to the interstitial Leydig cells. A moderate to strong activity of these three enzymes occurs during the period of functional maturity and accumulation of primary spermatogonia (figs. 1 and 2). At the beginning of the multiplication period, large numbers of steroid-synthesizing Leydig cells are centered around the tubules containing cell nests with primary and secondary spermatogonia. Later during this period, the enzyme reactions become weaker. In September, no activity of $3 \alpha-\mathrm{HSD}$ could be demonstrated. During the maturation period, $3 \beta-$ and $3 \alpha-\mathrm{HSD}$ activity of the Leydig cells remains unchanged while the G6PD activity increases. In November,

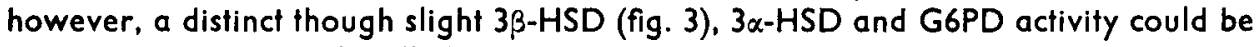
demonstrated in Sertoli cells lining post-spermatogonial cysts. At other times of the year these cells show a weak G6PD activity only.

The ultrastructure of the Leydig cells (fig. 4 ) is characterized by smooth endoplasmic reticulum (SER) and numerous mitochondria with tubular cristae and a dense matrix (MTC). This combination of cell organelles is characteristic of steroidogenesis. The Leydig cell cytoplasm also contains rough endoplasmic reticulum, free ribosomes, polysomes and Golgi-cisternae. Sertoli cells have a SER and a few round to tubular mitochondria with lamellar cristae (fig. 5). Lysosomes are characteristic of Sertoli cells lining seminiferous tubules containing residual sperm cells. Studies of November testes did not contribute to a solution of the structure of the mitochondria in the

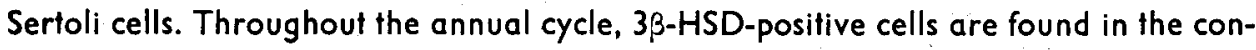
nective tissue surrounding the epithelium of the vas deferens (fig. 6). These stroma cells also show $3 \alpha-\mathrm{HSD}$ and G6PD activities. The fluctuation in enzyme activities of the stroma cells parallels the activity of the Leydig cells, with the strongest activity from January untill June, when sperm cells are stored in the lumen of the vas deferens. 


\section{Discussion.}

Leydig cells are the main source of testis steroids in teleosts (Lofts and Bern, 1972 ; van den Hurk, 1973). In rainbow trout, Leydig cells were considered as possible endocrine structures by Robertson (1958) and Oota and Yamamoto (1966). Boddingius (1975), among others, suggested an endocrine role for the lobule boundary cells of this species. EM-studies by Billard ef al. (1972), however, demonstrated the improbability of steroidogenesis in these cells; these latter workers found lobule boundary cells and Sertoli cells to be identical.

In our experiments, the presence of $3 \beta-H S D, 3 \alpha-H S D$ and G6PD activities, SER and MTC are indicative of steroidogenesis in Leydig cells of rainbow trout. Steroidogenic activity in Leydig cells appear to be strong in January, February and May, when ripe sperm cells are stored in the lumen of the testis tubules, indicating that steroids are involved in these processes. In June, the presence of steroid-synthesizing Leydig cells at sites where secondary spermatogonia are formed suggests a functional relationship. The localization of Leydig cells around cysts with spermatogonia and the epithelium of the efferent duct system in Poecilia latipinna, was considered to be indicative of intratesticular effects of androgens (van den Hurk, 1975). As compared to these findings, the distribution of steroid-synthesizing stroma cells around the epithelium of the vas deferens of the trout may indicate that steroids are involved in the functioning of the sperm duct. Although G6PD activity was found in the Sertoli cells throughout the annual cycle, $3 \beta$ - and $3 \alpha-H S D$ activities in these cells were observed in November only. This may indicate steroidogenesis in the Sertoli cells during this limited period, when the production of steroids in Leydig cells is comparatively low. As the presence of steroidogenic enzymes coincides with spermiation, steroid hormones possibly produced in the Sertoli cells might stimulate the transport of sperm cells from the testis tubules to the efferent duct system. This is in support of the findings of Yamazaki and Donaldson (1969) who in studies on the goldfish, Carassius auratus, were the

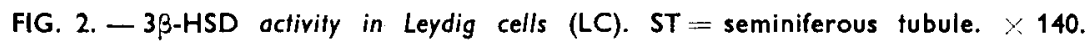

FIG. 3. - 3ß-HSD activity in Sertoli cells (SC) from November. $I=$ interstitium. $\times 140$.

FIG. 4. - Ultrastructure of a Leydig cell. Solid arrows indicate SER, dotted arrow indicates RER. MTC $=$ mitochondrium with tubular cristae ; $R=$ ribosomes. $\times 28000$.

FIG. 5. - Ultrastructure of a Sertoli cell (May). Solid arrows indicate SER, dotted arrow indicates RER. $M L C=$ mitochondrium with lamellar cristae ; $N=$ nucleus : $L=$ lumen of a seminiferous tubule $; S P=$ sperm cell $; l=$ interstitial tissue. $Y$. 13000 .

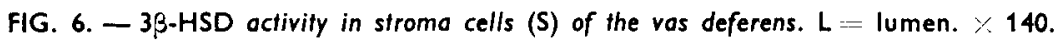




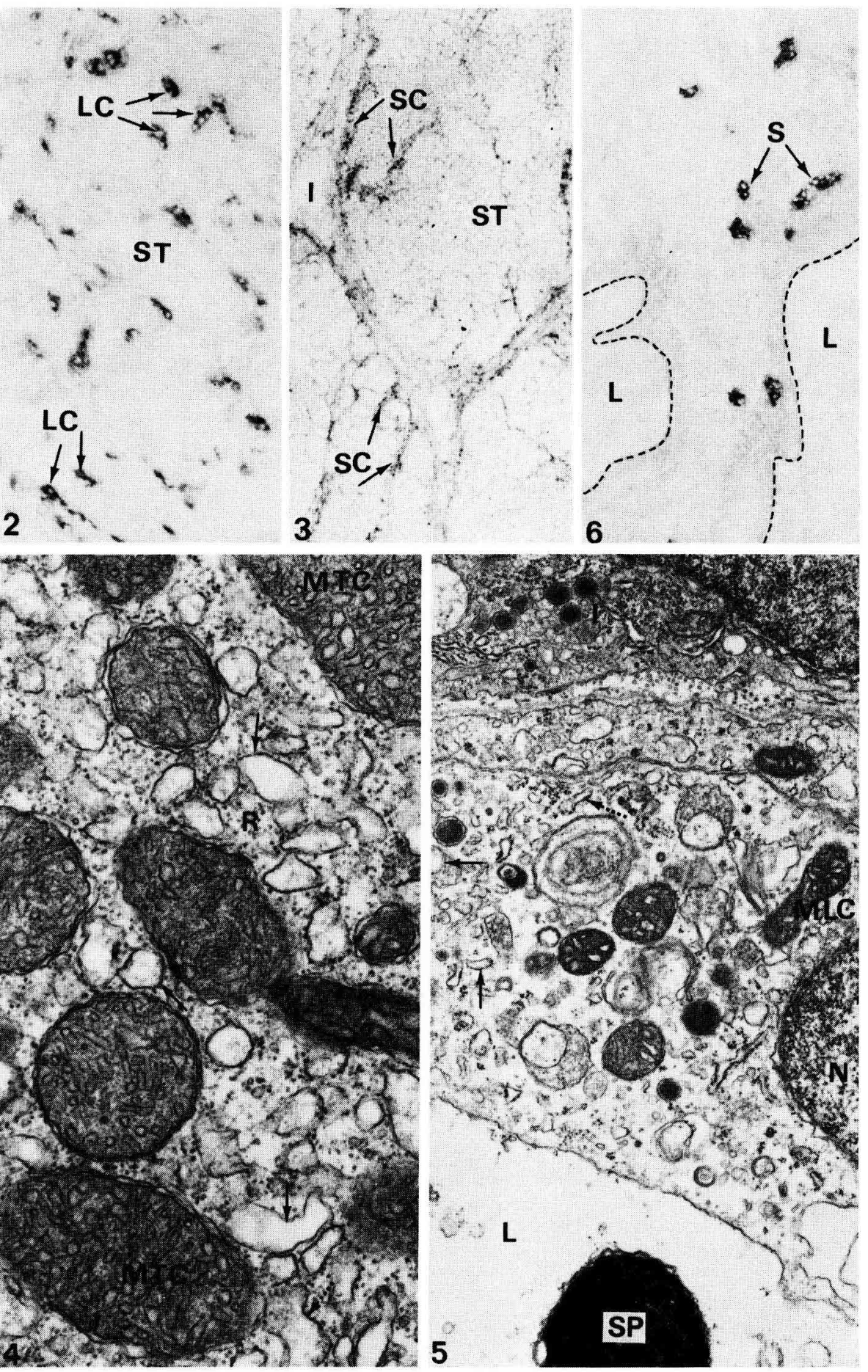


first to demonstrate a regulation of spermiation by androgens. In the present studies however, steroidogenesis in the Sertoli cells has not been proved by ultrastructural verification of the cytochemical results.

Symposium sur la Reproduction des Poissons Paimponf, France, 19-21 septembre 1977.

Résumé. L'histoenzymologie et la microscopie électronique montrent que les cellules de Leydig sont la source principale de stéroïdes dans le testicule de Salmo goirdneri. L'activité stéroïdogène de ces cellules est trouvée tout au long du cycle reproducteur, avec un pic d'activité de janvier à juin, quand les testicules sont matures et que de nouvelles spermatogonies se forment. En juin, les cellules de Leydig sont principalement localisées à la périphérie des tubules séminifères contenant des spermatogonies secondaires. Les enzymes de la stéroïdogenèse sont également présentes dans les cellules de Sertoli en novembre, pendant la spermiation. La synthèse de stéroïde a de plus été mise en évidence dans les cellules du stroma distribuées dans le tissu conjonctif autour de l'épithélium du vas deferens. L'activité stéroïdogène dans ces cellules du stroma est plus intense durant la période de stockage des spermatozoïdes dans la lumière du vas deferens que pendant d'autres phases du cycle reproducteur.

\section{References}

BILLARD R., JALABERT B., BRETONB., 1972. Les cellules de Sertoli des poissons téléostéens. I. Etude ultrastructurale. Ann. Biol. anim. Bioch. Bioph., 12, 19-32.

BODDINGIUS J., 1975. The cell types of the adenohypophysis in the rainbow trout Salmo irideus. A histological study. Thesis Univ. Groningen, Holywell Press Ltd., Oxford.

HENDERSON N. E., 1967. The urinary and genital systems of trout. J. Fish. Res. Bd. Con., 24, 447-449.

HURK, R. VAN DEN, 1973. The localization of steroidogenesis in the testes of oviparous and viviparous teleosts. Proc. kon. ned. Akad. Wet., C 76, 270-279.

HURK R. VAN DEN, 1975. Morphological and functional aspects of the testis of the black molly (Molliensia latipinna). Thesis, Univ. Utrecht.

LOFTS B., BERN H. A., 1972. The functional morphology of steroidogenic tissues, 37-126. In IDLER D. R., Steroids in non-mammalian verfebrates. Acad. Press, N. Y., London.

OOTA J., YAMAMOTO K., 1966. Interstitial celis in the immature testes of the rainbow trout. Ann. zool. Jap., 39, 142-148.

OOTA J., YAMAMOTO K., TAKANO K., SAKAGUCHI T., 1965. Studies in the maturing process in the rainbouw trout, Salmo goirdnerii irideus. Bull. Jap. Soc. Sci. vish., 31, 597-602.

PEUTE J., BRUYN M. G. A. de, SELDENRIJK R., OORDT P. G.W. J. VAN, 1976. Cytophysiology and innervation of gonadotropic cells in the pituitary of the black molly, Poecilia latipinna. Cell Tissue Res., 174, 35-54.

ROBERTSON O. H., 1958. Accelerated development of testis after unilateral gonadectomy with observations in normal testis of rainbow trout. Fish Bull. Fish. Wildlife Serv., 58, 9-30.

WEISEL G. F., 1943. A histological study of the testes of the sockeye salmon (Oncorhynchus nerka). J. Morphol., 73, 207-229.

YAMAZAKI F., DONALDSON E. M., 1969. Involvement of gonadotropin and steroid hormones in the spermiation of goldfish. Gen. comp. Endocrinol., 12, 491-497. 